\title{
Coronavirus-Like Particle COVID-19 Vaccine
}

National Cancer Institute

\section{Source}

National Cancer Institute. Coronavirus-Like Particle COVID-19 Vaccine. NCI Thesaurus. Code C173852.

A plant-derived virus-like particle (VLP) mimicking severe acute respiratory syndrome-coronavirus 2 (SARSCoV-2), with potential immunizing activity against SARS-CoV-2. Upon intramuscular administration of the coronavirus-like particle COVID-19 vaccine, the VLPS are taken up by antigen-presenting cells and present SARS-CoV-2 antigens to the immune system. This induces both a cell-mediated and an antibody-based immune response against SARS-CoV-2. The plant-based VLPs are non-infectious and replication-deficient versions of SARS-CoV-2 and mimic the shape and dimensions of the virus. 